\title{
The endoplasmic reticulum in pancreatic beta cells of type 2 diabetes patients
}

\author{
P. Marchetti • M. Bugliani • R. Lupi • L. Marselli • \\ M. Masini • U. Boggi • F. Filipponi • G. C. Weir • \\ D. L. Eizirik • M. Cnop
}

Received: 7 May 2007 / Accepted: 19 July 2007 / Published online: 30 September 2007

(C) Springer-Verlag 2007

\begin{abstract}
Aims/hypothesis Pancreatic beta cells have highly developed endoplasmic reticulum (ER) due to their role in insulin secretion. Since ER stress has been associated with beta cell dysfunction, we studied several features of beta cell ER in human type 2 diabetes.

Methods Pancreatic samples and/or isolated islets from non-diabetic controls (ND) and type 2 diabetes patients were evaluated for insulin secretion, apoptosis (electron microscopy and ELISA), morphometric ER assessment (electron microscopy), and expression of ER stress markers in beta cell prepared by laser capture microdissection and in isolated islets.
\end{abstract}

P. Marchetti $(\varangle) \cdot$ M. Bugliani $\cdot$ R. Lupi $\cdot$ M. Masini

Department of Endocrinology and Metabolism,

Metabolic Unit, Ospedale Cisanello, University of Pisa,

Via Paradisa 2,

56100 Pisa, Italy

e-mail: marchant@immr.med.unipi.it

L. Marselli • G. C. Weir

Joslin Diabetes Center, Harvard Medical School,

Boston, MA, USA

U. Boggi · F. Filipponi

Department of Oncology, Transplants and Advanced Technology,

University of Pisa,

Pisa, Italy

D. L. Eizirik $\cdot$ M. Cnop

Laboratory of Experimental Medicine, Faculty of Medicine,

Université Libre de Bruxelles,

Brussels, Belgium

M. Cnop

Division of Endocrinology, Erasmus Hospital,

Université Libre de Bruxelles,

Brussels, Belgium
Results Insulin release was lower and beta cell apoptosis higher in type 2 diabetes than ND islets. ER density volume was significantly increased in type 2 diabetes beta cells. Expression of alpha-mannosidase (also known as mannosidase, alpha, class 1A, member 1) and UDP-glucose glycoprotein glucosyl transferase like 2 (UGCGL2), assessed by microarray and/or real-time reverse transcriptase polymerase chain reaction (RT-PCR), differed between ND and type 2 diabetes beta cells. Expression of immunoglobulin heavy chain binding protein (BiP, also known as heat shock $70 \mathrm{kDa}$ protein 5 [glucose-regulated protein, $78 \mathrm{kDa}$ ] [HSPA5]), X-box binding protein 1 (XBP-1, also known as $X B P 1)$ and $\mathrm{C} / \mathrm{EBP}$ homologous protein $(\mathrm{CHOP}$, also known as damage-inducible transcript 3 [DDIT3]) was not higher in type 2 diabetes beta cell or isolated islets cultured at $5.5 \mathrm{mmol} / \mathrm{l}$ glucose (microarray and real-time RT-PCR) than in ND samples. When islets were cultured for $24 \mathrm{~h}$ at $11.1 \mathrm{mmol} / \mathrm{l}$ glucose, there was induction of $\mathrm{BiP}$ and $X B P-1$ in type 2 diabetes islets but not in ND islets.

Conclusions/interpretation Beta cell in type 2 diabetes showed modest signs of ER stress when studied in pancreatic samples or isolated islets maintained at physiological glucose concentration. However, exposure to increased glucose levels induced ER stress markers in type 2 diabetes islet cells, which therefore may be more susceptible to ER stress induced by metabolic perturbations.

Keywords Endoplasmic reticulum - Beta cell $\cdot \mathrm{BiP}$.

$\mathrm{C} / \mathrm{EBP}$ homologous protein $\cdot \mathrm{CHOP}$.

Immunoglobulin heavy chain binding protein .

Unfolded protein response $\cdot \mathrm{X}$-box binding protein $1 \cdot \mathrm{XBP}-1$

Abbreviations
BiP immunoglobulin heavy chain binding protein
CHOP C/EBP homologous protein




$\begin{array}{ll}\text { EM } & \text { electron microscopy } \\ \text { ER } & \text { endoplasmic reticulum } \\ \text { LCM } & \text { laser capture microdissection } \\ \text { MANI1A } & \text { alpha-mannosidase } \\ \text { UGCGL2 } & \begin{array}{l}\text { UDP-glucose glycoprotein glucosyl transferase } \\ \text { like 2 }\end{array} \\ \text { UPR } & \text { unfolded protein response } \\ \text { XBP-1 } & \text { X-box binding protein 1 } \\ \text { XBP-1s } & \text { spliced X-box binding protein 1 } \\ \text { XBP-1t } & \text { total X-box binding protein 1 }\end{array}$

\section{Introduction}

Diabetes mellitus is a chronic metabolic disease representing a major cause of morbidity and mortality in contemporary society [1-3]. Type 2 diabetes mellitus is the most common form of this disease (about $90 \%$ of all cases) and it is characterised by reduced insulin action and insulin deficiency $[1,4,5]$. Insulin resistance in peripheral tissues represents a serious and chronic challenge to the capacity of beta cells to produce and secrete insulin, and normoglycaemia is maintained as long as beta cells can compensate for insulin resistance. This imposes a stress on the beta cells, which may eventually fail to cope with the increased demand of insulin production, leading to the onset of diabetes [5-8]. The mechanisms causing the loss of beta cell function and mass in type 2 diabetes are still debated [8-10]. It has been recently proposed that alterations of endoplasmic reticulum (ER) function in the beta cell contribute to cell dysfunction and death [10-16]. The ER is central to several important cellular functions, including post-translational modifications, folding and assembly of newly synthesised secretory proteins, and calcium storage [14-16]. Because beta cells need to synthesise and secrete large quantities of insulin they have a well developed ER and a remarkable production of proteins involved in ER function [14-16]. When ER function is impaired, due for example to accumulation of mutant folding-incompetent proteins, calcium depletion, over-production of proteins, or viral infection, ER stress develops [10, 11, 14, 15]. Similarly, a mutation in insulin that causes its mal-folding leads to ER stress, beta cell death and diabetes in the Akita mouse [17]. Stressful conditions may be remedied by the ER through several adaptive mechanisms known as the unfolded protein response (UPR) [14-16]. The UPR includes expansion of ER size, enhanced folding capacity, reduction of protein synthesis at the transcriptional or translational level and increased clearance of unfolded proteins [14-16]. In case these mechanisms fail to clear the perturbation, the apoptosis programme is triggered [14-16].
Recent results further suggest that ER stress is one of the molecular mechanisms of pancreatic beta cell damage. In MIN6 cells, a mouse beta cell-derived cell line, nitric oxide depletes ER calcium stores and leads to apoptosis through induction of the ER stress associated apoptosis factor C/EBP homologous protein (CHOP) [18]. In addition, NEFAs cause induction of specific ER stress markers such as $\mathrm{X}$-box binding protein $1(X B P-1$, also known as $X B P 1)$, immunoglobulin heavy chain binding protein $(B i P$, also known as heat shock $70 \mathrm{kDa}$ protein 5 [glucose-regulated protein, $78 \mathrm{kDa}$ ] [HSPA5]), activating transcription factor 4 and 6 (ATF4 and ATF6), and CHOP (also known as damage-inducible transcript 3 [DDIT3]) in INS-1E cells, while cytokines cause a decrease in ER calcium and severe ER stress in INS-1E and primary beta cells $[10,11,13,19$ 21]. In vivo, a mutation in eukaryotic translation initiation factor 2 alpha kinase 3 (EIF2AK3, also known as PERK) impairs the development of a normal UPR and causes neonatal diabetes in Wolcott-Rallison syndrome [22]. Increased beta cell sensitivity to ER stress and apoptosis are also observed in the Perk-deficient mouse and in mice homozygous for a eukaryotic translation initiation factor $2 \mathrm{a}$ (Eif2a) serine 51 to alanine substitution [23]. Mice heterozygous for this amino acid substitution in Eif2a develop beta cell failure and diabetes when placed on a high-fat diet [24]. Whether and to what extent ER stress plays a role in beta cell dysfunction and death in human type 2 diabetes is largely unknown. In a recently published report, increased protein levels of $\mathrm{BiP}$ and $\mathrm{CHOP}$ were observed in pancreatic sections of type 2 diabetic patients [25]. In addition, beta cell nuclear $C H O P$ was found to be expressed at higher level in type 2 diabetic than nondiabetic pancreatic autopsy samples [26].

The present study examined several features of pancreatic beta cell ER in human type 2 diabetes. Morphological, functional and survival studies were performed on islets from multiorgan donors with or without type 2 diabetes, and the expression of ER stress-related mRNAs was evaluated in beta cell enriched samples obtained by laser capture microdissection (LCM) and isolated islets. Analyses were also performed after exposure of islets to increased glucose concentrations, to mimic a 'diabetic' environment in vitro.

\section{Methods}

Pancreas procurement and islet isolation Pancreases were obtained with the approval of the local Ethics Committee and processed as described [27-29]. Thirty-one glands were used. Table 1 reports the main characteristics of organ donors and islet preparations, showing no significant difference between non-diabetic and type 2 diabetic donors 
Table 1 Main characteristics of pancreas donors and islet preparations

\begin{tabular}{lllllllll}
\hline & $n$ & $\begin{array}{l}\text { Age } \\
\text { (years) }\end{array}$ & $\begin{array}{l}\text { Sex (male/ } \\
\text { female) }\end{array}$ & $\begin{array}{l}\text { BMI } \\
\left(\mathrm{kg} / \mathrm{m}^{2}\right)\end{array}$ & $\begin{array}{l}\text { Cause of } \\
\text { death }\end{array}$ & $\begin{array}{l}\text { Plasma glucose } \\
(\mathrm{mmol} / \mathrm{l})\end{array}$ & $\begin{array}{l}\text { Pancreas cold ischaemia } \\
\text { time }(\mathrm{h})\end{array}$ & $\begin{array}{l}\text { Islet purity } \\
(\%)\end{array}$ \\
\hline $\begin{array}{l}\text { Non-diabetic } \\
\text { donors }\end{array}$ & 22 & $61 \pm 15$ & $10 / 12$ & $25.8 \pm 3.4$ & $19 \mathrm{CVD}, 3$ trauma & $9.2 \pm 1.3$ & $12 \pm 3$ \\
$\begin{array}{l}\text { Type 2 } \\
\text { diabetes }\end{array}$ & 11 & $64 \pm 11$ & $8 / 3$ & $27.1 \pm 3.2$ & $11 \mathrm{CVD}$ & $13.9 \pm 1.8^{*}$ & $12 \pm 4$ & $52 \pm 11^{* *}$ \\
\hline
\end{tabular}

Plasma glucose values were available for 18 non-diabetic and seven diabetic patients. Islet purity was estimated by dithizone staining CVD cerebrovascular disease

$* p<0.01$ and $* * p=0.02$ vs non-diabetic donors

with regard to age, BMI, cause of death and pancreas cold ischemia time. Two diabetic patients were on dietary treatment, seven were treated with oral glucose-lowering agents (one sulphonylurea, two metformin, five sulphonylurea plus metformin) and two were on insulin. Isolated islet purity (estimated by dithizone staining) was higher in the preparations from non-diabetic donors. For morphological and morphometric studies, as well as for LCM experiments, pancreatic samples were obtained immediately before islet preparation. Islet isolation was performed by enzymatic digestion and density gradient purification [27-29]. Handpicked islets were kept at $37^{\circ} \mathrm{C}$ in a $\mathrm{CO}_{2}$ incubator for $3-$ 6 days before the experiments were performed, with no difference between non-diabetic and diabetic islets in terms of length of incubation. Culture medium consisted of M199 medium, containing $5.5 \mathrm{mmol} / 1$ glucose, 10\% (vol./vol.) bovine serum and antibiotics [27-29]. In a separate series of experiments, islets were cultured for an additional $24 \mathrm{~h}$ in the presence of $11.1 \mathrm{mmol} / \mathrm{l}$ glucose to assess the impact of increasing glucose concentration on some of the studied parameters.

Insulin secretion studies Insulin secretion studies were performed by batch incubation [27-29] in 22 control and nine type 2 diabetic preparations. Islet samples were kept at $37^{\circ} \mathrm{C}$ for $45 \mathrm{~min}$ in Krebs-Ringer bicarbonate (KRB), 0.5\% (vol./vol.) albumin, pH 7.4, containing $3.3 \mathrm{mmol} / 1$ glucose (washing phase). Then, the medium was replaced with KRB containing $3.3 \mathrm{mmol} / \mathrm{l}$ glucose to assess basal insulin secretion during $45 \mathrm{~min}$, after which the islets were challenged with $16.7 \mathrm{mmol} / 1$ glucose to assess glucosestimulated insulin release. Insulin was quantified using an immunoradiometric assay (Pantec Forniture Biomediche, Turin, Italy).

Evaluation of beta cell apoptosis Beta cell apoptosis was assessed by electron microscopy (EM; see below) in six non-diabetic and five diabetic pancreases, based on the typical morphological alterations (chromatin condensation, bleb formation, budding of apoptotic bodies) [27, 29]. Islet cell death was also assessed by the Cell Death Detection
ELISAplus assay (Roche Diagnostics, Milan, Italy) in 18 control and eight type 2 diabetic preparations. This assay evaluates cytoplasmic histone-associated DNA fragments. The procedure was performed as previously described [28]. Duplicate aliquots of approximately 15 islets of comparable size were incubated for $30 \mathrm{~min}$ with a lysis buffer at room temperature and then centrifuged at $200 \times \mathrm{g}$ for $10 \mathrm{~min}$ at $4^{\circ} \mathrm{C}$. A sample of the supernatant fraction $(20 \mu \mathrm{l})$ was placed in streptavidin-coated microtiter wells and incubated for $120 \mathrm{~min}$ with $80 \mu \mathrm{l}$ of a mixture containing antihistone-biotin antibody and anti-DNA-peroxidase antibody. After washing and $15 \mathrm{~min}$ incubation with $100 \mu \mathrm{l}$ of a solution containing 2,2'-azinobis-(3-ethylbenzthiazoline-6sulfonate) (substrate for peroxidase), absorbance of the samples was read spectrophotometrically at $405 \mathrm{~nm}$.

EM evaluation Pancreatic samples were fixed with $2.5 \%$ (vol./vol.) glutaraldehyde in $0.1 \mathrm{mmol} / 1$ cacodylate buffer, $\mathrm{pH} 7.4$ for $1 \mathrm{~h}$ at $4^{\circ} \mathrm{C}$, and then postfixed in $1 \%$ (vol./vol.) cacodylate-buffered osmium tetroxide for $2 \mathrm{~h}$ at room temperature. Samples were dehydrated in a graded series of ethanol, transferred to propylene oxide and embedded in Epon-Araldite. Ultrathin sections (60-80 nm thick) were cut with a diamond knife, placed on formvar/carbon-coated copper grids (200 mesh), and stained with uranyl acetate and lead citrate. Morphometric analyses were performed as previously described [27-29]. Micrographs, obtained at $\times 10,000$, were analysed by overlay with a graticule $(11 \times$ $11 \mathrm{~cm}$ ) composed of 169 points. For the study of ER, volume density was calculated according to the formula: volume density $=P i / P t$, where $P i$ is the number of points within the subcellular component and $P t$ is the total number of points, and expressed as $\mathrm{ml} / 100 \mathrm{ml}$ tissue $(\mathrm{ml} \%)$. Three to four islets per pancreas were studied, and 24 beta cells per islet were analysed, leading to 456 and 432 beta cells evaluated in non-diabetic and type 2 diabetic samples, respectively.

LCM experiments Pancreases from four type 2 diabetic donors and four matched controls were studied. LCM was performed as previously described [30]. Frozen pancreatic 
sections were dehydrated, completely air-dried and LCM was performed using PixCell II LCM System (Arcturus Engineering, Mountain View, CA, USA). Laser capture was performed under direct microscopic visualisation of the beta cells, identified by their autofluorescence in islets with no or minimal signs of amyloid deposits [30]. The microdissected cells were incubated with guanidine thiocyanate and polyethylene glycol octylphenol ether-based buffer for 30 min at $42^{\circ} \mathrm{C}$ and RNA was extracted by modification of the RNA microisolation protocol $[31,32]$. Total RNA was amplified using the RiboAmp HS RNA Amplification Kit (Arcturus). After two rounds of amplification, RNA quantity was determined by evaluating the absorbance at 260 and $280 \mathrm{~nm}$, and quality was assessed by running samples on Agilent 2100 Bioanalyzer (Agilent Technologies, Santa Clara, CA, USA). Biotinylated RNA was generated using the BioArray High Yield RNA Transcript Labeling Kit (Enzo Diagnostics, Farmingdale, NY, USA). RNA products were fragmented and hybridised to GeneChip Human X3P Array (Affymetrix, Santa Clara, CA, USA). The array data were normalised and analysed using DNA-Chip Analyzer (dChip) software (available from: http://biosun1.harvard.edu/complab/dchip/, last accessed in August 2007) that assesses the standard errors for the expression indexes and calculates confidence intervals for fold changes. Lower confidence bound (LCB) is a conservative estimate of the fold change. An LCB cut-off value of 1.2 is used to assess differentially expressed genes. The complete array data will be reported elsewhere (L. Marselli, D.C. Sgroi, J. Thorne, S. Dahiya, S. Torri, A. Sharma, S. Bonner-Weir, P. Marchetti, G.C. Weir, personal communication).

Quantitative measurements of specific transcripts were acquired by real-time RT-PCR. cDNA templates were synthesised from $1.0 \mu \mathrm{g}$ of amplified RNA (aRNA) using TaqMan Reverse Transcription Reagents (Applied Biosystems, Foster City, CA, USA). TaqMan Universal PCR Master Mix (Applied Biosystems) was used for real-time PCRs in presence of $0.1 \mathrm{ng} \mathrm{cDNA}, 1 \mu \mathrm{mol} / \mathrm{l}$ primers and $0.25 \mathrm{nmol} / \mathrm{l}$ probe in a total volume of $20 \mu \mathrm{l}$. The following primers were used: for $B i P$, forward (F) 5'-ACCAATTATC AGCAAACTCTATGGAA-3', reverse (R) 5'-CAT CTTTTTCTGCTGTATCCTCTTCA-3' (74 bp); for alphaglucosidase $(G A A)$, F 5'-TTTTTATGCCCCACCGATACA3', R 5'-CACTCCTTTGATCCATTCATCCT-3' (68 bp); for alpha-mannosidase (MAN1A1), F 5'-GAGGGCTGG ACGGCAAGT-3'， R 5'-ATCTCCACCGAAAAGACCC ATT-3' (68 bp); for UDP-glucose glycoprotein glucosyl transferase like 2 (UGCGL2), F 5'-TGATCTGTGCAATAA TCCCAAAA-3', R 5'-GCATCATACTCCACCCATTCTG$3^{\prime}$ (84 bp); for XBP-1, F 5'-TTGTCACCCCTCCAGAA CATC-3'， R 5'-CAGGATATCAGACTCTGAATCT GAAGA-3' (74 bp); and for RPL32 (used as reference) F
5'-CTGGCCATCAGAGTCACCAA-3'， R 5'-TGA GCTGCCTACTCATTTTCTTCA-3' (65 bp). Primers and probes were designed using Primer Express software (Applied Biosystems) and were purchased from MWGBiotech. Quantitative PCR was performed on an Applied Biosystems 7300 Real Time PCR System. The efficiencies of amplification were evaluated and compared with that of the reference gene RPL32, resulting in $>97 \%$ similarity. Each sample was analysed by three amplifications and average measurements were taken for analysis. The relative abundance of mRNA was calculated by the comparative cycle threshold (CT) method, i.e. the fractional cycle number at which the amount of amplified target reaches a fixed threshold. Normalisation of target gene expression was performed by computing the difference in the CT values derived from the target and the reference genes $\mathrm{CT}$ value $(\Delta \mathrm{CT})$.

Quantitative RT-PCR experiments in isolated islets Total RNA was extracted using the RNeasy protect mini kit (Qiagen, Santa Clarita, CA, USA) in Pisa from 14 nondiabetic and 11 diabetic islet preparations as previously described [28]. cDNA was synthesised from $2 \mu \mathrm{g}$ RNA. mRNA expression was measured by real-time RT-PCR reaction. Total RNA was quantified by absorbance at $\mathrm{A}_{260} /$ $\mathrm{A}_{280}$ (ratio $\left.>1.65\right) \mathrm{nm}$ in a Perkin-Elmer spectrophotometer (Waltham, MA, USA). Its integrity was assessed after electrophoresis through $1.0 \%$ (wt/vol.) agarose gels by ethidium bromide staining. For the determination of ER stress-related mRNAs, coded cDNA samples were sent to the Laboratory of Experimental Medicine at the Université Libre de Bruxelles. After completion of the real time RTPCR, the code for the samples was broken. The real time RT-PCR amplification reaction was performed in $20 \mu \mathrm{l}$ containing $3 \mathrm{mmol} / 1 \mathrm{MgCl}_{2}, 0.5 \mu \mathrm{mol} / \mathrm{l}$ forward (F) and reverse (R) primers, $2 \mu \mathrm{l}$ FastStart SYBR Green mix (Roche), and $2 \mu \mathrm{l}$ cDNA. Standards for each gene were prepared in conventional PCR using the following primers: CHOP, F 5'-AGGCACTGAGGGTATCATGTT-3', R 5'CTGTTTCCGTTTCCTGGTTC-3' (480 bp); BiP, F 5'TTCTTGTTGGTGGCTCGACT-3'， R 5'-GTCAGC ATCTTGGTGGCTTT-3' (758 bp); spliced XBP-1 (XBP$1 \mathrm{~s}), \quad \mathrm{F} \quad 5^{\prime}$-CCGCAGCAGGTGCAGG-3'， $\mathrm{R}$ 5' GGGGCTTGGTATATATGTGG-3' (325 bp); total XBP-1 (XBP-1t), F 5'-CCTTGTAGTTGAGAACCAGG-3', R 5'GGGGCTTGGTATATATGTGG-3' (824 bp). Purified PCR products were quantified fluorometrically using SYBR Green, and their concentration was calculated as copies/ microliter by comparison with a standard curve [11, 33]. The expression level of mRNA under study was corrected for that of the housekeeping gene $\beta$-actin and multiplied by 100 for $B i P$ and $X B P-1$ and by 1,000 for $C H O P$. $\beta$-Actin expression in human islets was not modified by culture at 
different glucose concentrations or by exposure to the diabetic environment in vivo (data not shown). The specific real-time primers for $B i P$ and $C H O P$ were purchased from Qiagen (QuantiTect HS HSPA5 and DDIT3, Venlo, the Netherlands). $\beta$-Actin, $X B P-1 \mathrm{~s}$ and $X B P$-1t primers have been reported elsewhere [34]. Amplification efficiencies for the different primers were $>97 \%$ similar.

Statistical analysis Results are expressed as mean $\pm \mathrm{SD}$, unless stated otherwise. Comparison of groups was made by the two-tailed Student's $t$ test for unpaired or paired data, as appropriate (see Results).

\section{Results}

Islet insulin secretion and apoptosis We first assessed the function and survival of islets prepared from diabetic and non-diabetic organ donors. In response to $3.3 \mathrm{mmol} / \mathrm{l} \mathrm{glu}-$ cose, insulin release did not differ significantly between nondiabetic and type 2 diabetic islets (Fig. 1a). However, when challenged with $16.7 \mathrm{mmol} / 1$ glucose, diabetic islets released a lower amount of insulin (Fig. 1a). Apoptosis was determined by EM and by measuring histone-associated DNA fragments. By EM (performed on pancreatic samples before islet isolation), 1,405 non-diabetic and 2,303 diabetic islet cells were counted, and the percentage of apoptotic beta cells was significantly higher in type 2 diabetic islets (Fig. 1b). When apoptotic beta cells were subdivided according to the presence of signs of early apoptosis (chromatin condensation along the perimeter of the nucleus) or advanced apoptosis (such as complete condensation of nuclear chromatin), the respective percentages were 46 and $54 \%$ of beta cells of type 2 diabetic donors. Representative EM of a normal and an apoptotic beta cell are given in Fig. 2. When the amount of islet cell death was determined by an ELISA method in isolated islets, similar results were obtained (Fig. 1c). These findings corroborate previous observations [27, 28, 35-38] and confirm that pancreatic beta cells in human type 2 diabetes have impaired function and increased demise.

EM studies of ER This part of the study was performed by analysing beta cells without signs of apoptosis, in samples obtained before islet isolation. The ER was more readily visible in diabetic than non-diabetic beta cells (Fig. 3a,b). Concentrically arranged, not dilated cisternae (Fig. 3a,b) and strongly electron-dense ribosomes bound to the ER membranes (Fig. 3a,b) were observed. ER volume density in type 2 diabetic beta cells was the double of control beta cells ( $1.7 \pm 0.1$ vs $0.9 \pm 0.06 \mathrm{ml} \%, p<0.01$ (Fig. $3 \mathrm{c}$ ). These findings indicate an increased overall size of ER in beta cells of type 2 diabetic patients.

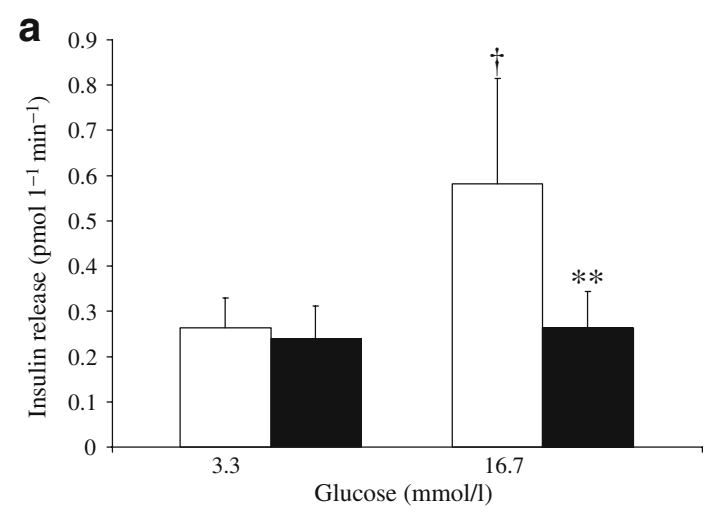

b
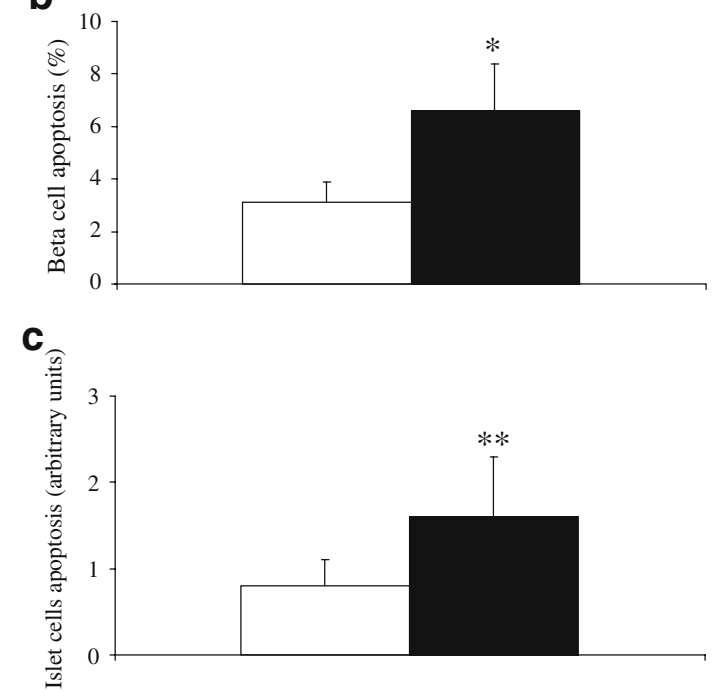

Fig. 1 Insulin secretion and apoptosis from non-diabetic (open bars) and type 2 diabetic (closed bars) islet cells. a Insulin secretion did not differ in response to $3.3 \mathrm{mmol} / \mathrm{l}$ glucose, but it was significantly lower with islets from type 2 diabetic donors compared with controls in response to $16.7 \mathrm{mmol} / \mathrm{l}$ glucose. $\mathbf{b}$ The percentage of apoptotic beta cells assessed by EM in pancreatic samples was significantly higher in type 2 diabetic islets. c Apoptosis, assessed by ELISA in isolated islets, was significantly higher in the diabetic preparations. ${ }^{\dagger} p<0.01 \mathrm{vs}$ release from non-diabetic islets at $3.3 \mathrm{mmol} / \mathrm{l}$ glucose (Student's $t$ test for paired data); $* p<0.05$ and $* * p<0.01$ vs non-diabetic islets (Student's $t$ test for unpaired data)

Gene expression studies in beta cell-enriched samples By using LCM, beta cell-enriched samples were obtained from non-diabetic and diabetic pancreatic samples, and microarray analysis performed. Whereas the complete description of the microarray data will be reported elsewhere (L. Marselli, D.C. Sgroi, J. Thorne, S. Dahiya, S. Torri, A. Sharma, S. Bonner-Weir, P. Marchetti, G.C. Weir, unpublished results), for the purpose of the present study we focused on ER-related genes. None of the 692 genes examined differed between control and diabetic samples, according to LCB values (not shown), with the exception of MAN1A1 (LCB value: -1.44 , upregulated in type 2 diabetes) and UGCGL2 (LCB value: 1.51 , downregulated in type 2 diabetes). The expression of these two genes and that of BiP and XBP-1 (key markers of 
Fig. 2 EMs showing a normal beta cell (a) and a beta cell with signs of advanced apoptosis (b). Magnification $\times 10,000$. IG, insulin granules; $\mathrm{N}$, nucleus; $\mathrm{CC}$, chromatin condensation

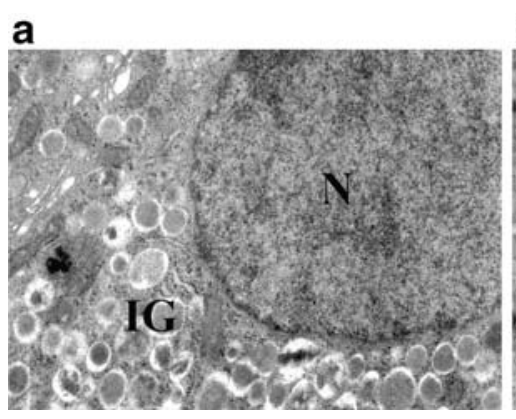

b

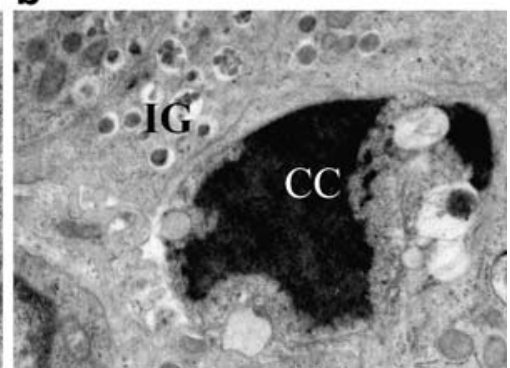

ER stress) were further evaluated by real-time RT-PCR. It was shown that only the difference for $U G C G L 2$ reached the threshold of statistical significance $(\Delta \mathrm{Ct}$ : $9.987 \pm 0.052$ in controls and $9.091 \pm 0.598$ in type 2 diabetes, $p=0.05$ ), whereas the other genes did not differ between non-diabetic and type 2 diabetic samples, with respective $\Delta \mathrm{Ct}$ values of $6.649 \pm 0.842$ and $5.771 \pm 1.715$ for $B i P(p=0.40), 4.736 \pm$ 0.314 and $5.258 \pm 0.457$ for MAN1A1 $(p=0.11), 4.887 \pm$ 0.562 and $4.646 \pm 0.534$ for $X B P-1 \quad(p=0.55)$. These results suggest that beta cells obtained from the pancreases of type 2 diabetic patients have only minor differences in ER stress marker gene expression compared with control beta cells.

Gene expression studies in isolated islets The expression of selected ER stress markers was studied in isolated islets cultured for 3-6 days at $5.5 \mathrm{mmol} / \mathrm{l}$ glucose. Real-time RTPCR results showed that when compared with control islet preparations $(n=14)$, diabetic islets $(n=11)$ had similar or even lower expressions of the studied genes. The respective values (reported as gene over $\beta$-actin expression) in nondiabetic and type 2 diabetic islets were: for $C H O P, 7 \pm 2$ vs $5 \pm 2(\mathrm{NS})$; for $B i P, 21 \pm 4$ vs $9 \pm 2(p<0.02)$; for $X B P-1 \mathrm{~s}$, $46 \pm 4$ vs $18 \pm 3(p<0.001)$; for $X B P-1 \mathrm{t}, 89 \pm 12$ vs $31 \pm 6$ ( $p<$ $0.001)$. When isolated islets were exposed for $24 \mathrm{~h}$ to $11.1 \mathrm{mmol} / \mathrm{l}$ (Fig. 4a,b), the studied mRNAs remained unchanged in islets from non-diabetic donors (Fig. 4a). However, in type 2 diabetic islets the exposure to high glucose caused the induction of $B i P$ and $X B P-1$ t, the values of which, although not statistically different from nondiabetic samples, were significantly higher than those of untreated diabetic islets (Fig. 4b). A trend for an increase in $X B P$ - $1 \mathrm{~s}$ mRNA $(p=0.06)$ in type 2 diabetic islets was also observed (Fig. 4b). Thus, when compared with non-diabetic preparations, islets isolated from type 2 diabetic patients and enabled to recover for 3-6 days in a 'near-physiological' environment had unchanged or decreased expression of ER stress markers; they show, however, increased susceptibility to ER stress induced by a metabolic perturbation.

\section{Discussion}

The ER is responsible for the synthesis, modification and delivery of proteins to their target sites. These processes may be impaired under various physiological and pathological conditions, leading to ER stress $[12,14-16]$. To survive under ER stress conditions, cells trigger adaptive, self-protective mechanisms, which are collectively termed ER stress response (also named UPR) [14-16]. These include increasing the size of ER, upregulation of the ER folding capacity through modulation of chaperones and foldases, downregulation of the biosynthetic load, and increased clearance of unfolded proteins through promotion

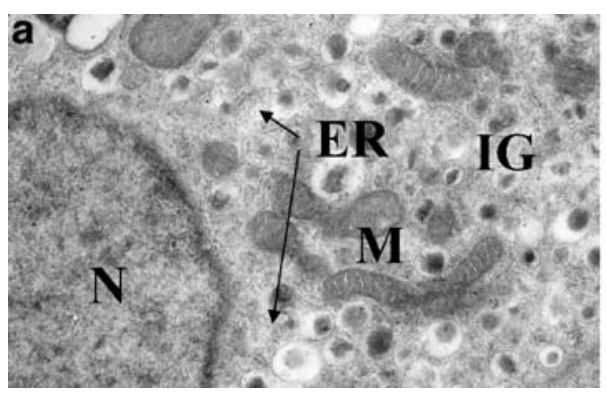

Fig. 3 a,b EMs showing the ER in non-diabetic (a) and type 2 diabetic (b) beta cells. The ER components (arrows) were scarcely visible in non-diabetic cells and more apparent in type 2 diabetes mellitus. Magnification $\times 10,000$. IG, insulin granules; N, nucleus; $M$,
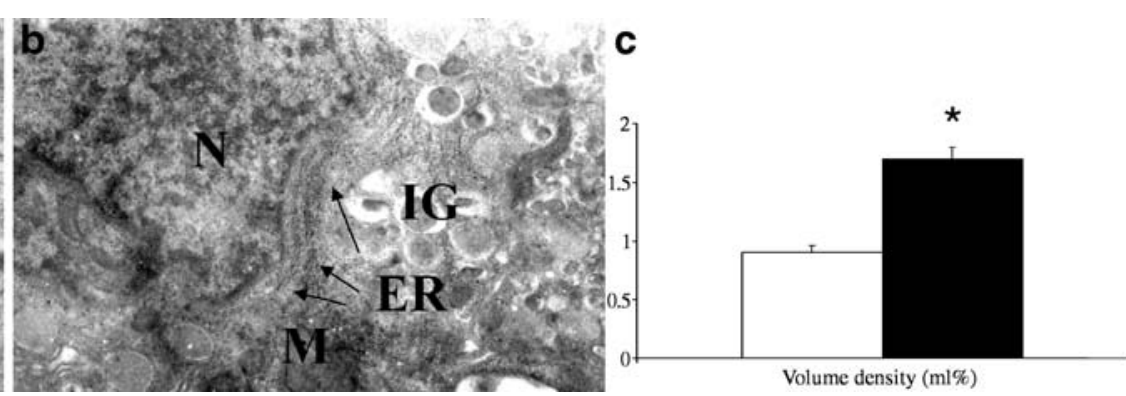

Volume density $(\mathrm{ml} \%)$

mitochondria. c ER density volume was significantly higher in type 2 diabetic beta cells (closed bar) compared with non-diabetic beta cells (open bar). ${ }^{*} p<0.05$ (Student's $t$ test for unpaired data) 
a
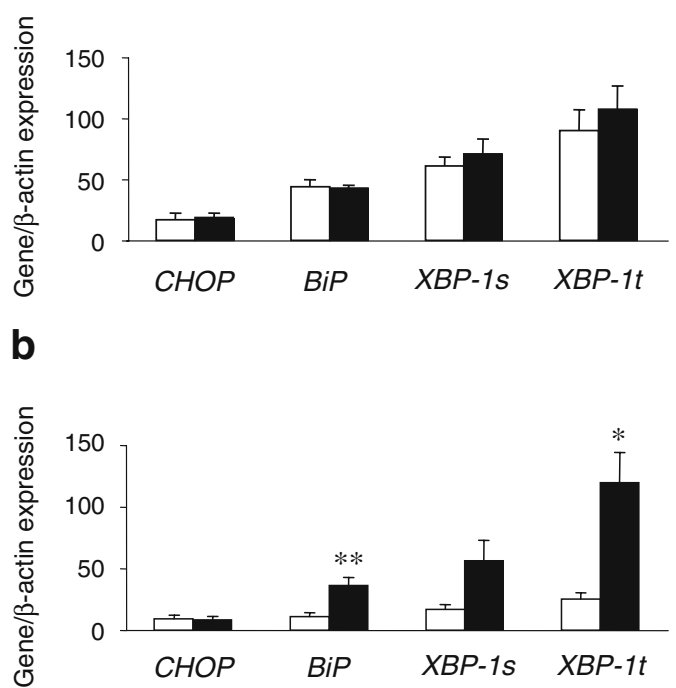

Fig. 4 ER stress markers in non-diabetic (a) and type 2 diabetic islets (b). mRNA expression was analysed by real time RT-PCR and normalised for the expression of the housekeeping gene $\beta$-actin. Islets were cultured for 3-6 days in medium containing $5.5 \mathrm{mmol} / 1$ glucose and then for an additional $24 \mathrm{~h}$ at $5.5 \mathrm{mmol} / 1$ glucose (open bars) or $11.1 \mathrm{mmol} / 1$ glucose (closed bars). The results represent means $\pm \mathrm{SE}$ of three (a) and five (b) different human islet preparations. ${ }^{*} p<0.05$, ${ }^{* *} p<0.01$ for the comparison $5.5 \mathrm{vs} 11.1 \mathrm{mmol} / 1$ glucose (Student's $t$ test for paired data)

of ER associated degradation [12, 14-16]. When these mechanisms do not remedy the stress situation, apoptosis is initiated. Since a number of articles have recently reported that ER stress may be implicated in beta cell dysfunction and death in diabetes [10-16, 19-26], in the present study we evaluated features of ER function/dysfunction in human beta cells from type 2 diabetic organ donors.

First, we confirmed that diabetic beta cells have functional and survival defects, as previously shown by us and others [27, 28, 35-38]. Specifically, decreased glucosestimulated insulin release and increased apoptosis were observed (Figs. 1 and 2). It has been previously reported that this may be associated with reduced insulin content, lower insulin granule amount, diminished islet insulin mRNA and increased caspase activation [27, 28, 33].

Then, by ultrastructural analysis we observed that the density volume of ER in diabetic beta cells is significantly higher than in non-diabetic cells (Fig. 3). Increased ER size is considered an early adaptive response to ER stress [1416, 39]. This feature has been observed in beta cells during the development of type 2 diabetes in the New Zealand Obese mouse [40], and, more recently, also in beta cells of the Akita mouse, a monogenic diabetes model caused by a missense mutation of the insulin 2 gene [21], which leads to accumulation of mutant proinsulin and severe ER stress. In the Akita mouse beta cells, the volume density of ER was increased by 1.7 -fold [41], which is similar to our findings in human diabetic beta cells.

Next, we assessed the expression of several genes encoding for proteins involved in ER function, including BiP, MAN1A1, UGCGL2, XBP-1 and CHOP. BiP belongs to the family of molecular chaperones facilitating protein folding; MAN1A1 and UGCGL2 are carbohydrateprocessing enzymes [12, 14-16]. In particular, MAN1A1 digests and UGCGL2 attaches a single glucose residue from/to the Man9GlcNAc2 glycan of incompletely folded or misfolded amino acid sequences [42, 43]. In doing so, these proteins are involved in quality control of the folding/ unfolding processes [44]. XBP-1 is a transcription factor that is activated through alternative splicing (XBP-1s) under ER stress [33], and CHOP contributes to the induction of ER-stress-mediated apoptosis [45]. For gene expression experiments, we used isolated islets or beta cell preparations obtained by LCM. This technique makes it possible to obtain small quantities of tissue from frozen sections, enabling collection of beta cell enriched preparations $[31,32]$. RNA was subsequently analysed by microarray and real-time RT-PCR [31, 32]. Microarray analysis of non-diabetic and type 2 diabetic beta cell preparations showed altered expression of MAN1A1 and UGCGL2, and the latter was confirmed by RT-PCR. Although no previous information regarding the expression of $U G C G L 2$ in diabetes is available, our results suggest that beta cells of type 2 diabetic patients may have defects in some steps of the ER glycoprotein quality control system. These defects, however, seem minor, as we observed no change in the expression of most ER stress related genes, including $B i P$, $X B P-1$ and $C H O P$. Accordingly, when islets were isolated and maintained for a few days at normal glucose concentration, diabetic cells showed similar or even decreased expression of $B i P, X B P-1 \mathrm{~s}, X B P-1 \mathrm{t}$ and $C H O P$. Although somewhat unexpected, this finding is in line with previous observations that some ER stress markers, such as ATF4 and $A T F 3$, go below control levels during recovery from cyclopiazonic acid-induced ER stress in rat beta cells [33]. In addition, the percentage of XBP-1s : XBP-1t ratio was found to be $39 \pm 3 \%$ in control beta cells and $12 \pm 2 \%$ in beta cells treated for $6 \mathrm{~h}$ with CPA and then allowed to recover for $3 \mathrm{~h}(n=3, p=0.02)$ (P. Pirot and D. L. Eizirik, unpublished data). This, and the observation that following several different hypoglycaemic treatments XBP-1 and BiP are downregulated in the liver of chronically hyperglycaemic $d b / d b$ mice, compared with normoglycaemic $d b /+$ mice [46], raises the intriguing possibility that the late recovery period from ER stress may be characterised by decreased expression of UPR markers. The available data, however, 
do not allow any firm conclusion on this issue at present, and additional experiments need to be designed to test this possibility.

Altogether, therefore, human beta cells from type 2 diabetic donors do indeed show some signs of increased ER stress, which is however mild enough not to elicit unremediable downstream events. Since apoptosis was detected both in diabetic pancreas samples and isolated islets, and insulin secretion defects were documented with isolated islets, factors others than ER stress may play a prominent role in beta cell dysfunction and death in type 2 diabetes. Alternatively, we may have been unable to detect major signs of ER stress because of dynamic regulation of the ER stress response [33], as discussed above. At odds with the present findings, it has been recently reported that $\mathrm{BiP}$ and $\mathrm{CHOP}$, as assessed by immunostaining of post mortem pancreatic sections, were present at higher levels in the islets of type 2 diabetic patients than in those of controls $[25,26]$. The discrepancy may be due to differences in the experimental protocols. In particular, we used samples derived from pancreases processed for transplantation, whereas in previous studies $[25,26]$ autopsy samples were used $[25,26]$, which may be subject to post mortem changes and alterations in intracellular calcium handling [47].

Interestingly, we observed that in isolated islets exposed to moderately high glucose concentrations $(11.1 \mathrm{mmol} / \mathrm{l})$

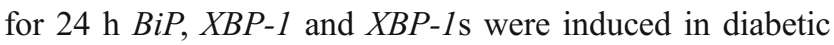
islets, but not in non-diabetic preparations (Fig. 4). Prolonged exposure of beta cells to increased glucose levels can cause ER stress and oxidative stress (oxidative stress may worsen ER stress) $[10,48,49]$. We and others have previously reported that beta cell defences against oxidative stress are reduced in the case of diabetes $[28,50]$. It is therefore possible that diabetic beta cells have a higher susceptibility to ER stress induced by metabolic perturbations. This would fit with the scenario in which beta cells in type 2 diabetes face a condition of ER stress that is relatively compensated for periods of time, but exacerbates in case of metabolic decompensation (i.e. high plasma glucose levels), thus contributing to beta cell damage. If true, this would provide additional reason to avoid even transient hyperglycaemia in patients with type 2 diabetes in order to preserve beta cell functional mass.

Acknowledgements This work was supported by the European Union (Integrated Project EuroDia LSHM-CT-2006-518153 in the Framework Programme 6 of the European Community), the European Association for the Study of Diabetes/European Foundation for the Study of Diabetes/Pfizer Resource Award, the Fonds National de la Recherche Scientifique, Fonds de la Recherche Scientifique Médicale, and Actions de Recherche Concertées de la Communauté Française, Belgium (to D. L. Eizirik). We thank A. K. Cardozo for helpful discussions and designing some of the primers, and G. Vandenbroeck for expert technical assistance with real time RT-PCR.

\section{References}

1. American Diabetes Association (2007) Diagnosis and classification of diabetes mellitus. Diabetes Care 30:S42-S47

2. Hossain P, Kawar B, El Nahas M (2007) Obesity and diabetes in the developing world $-\mathrm{a}$ growing challenge. $\mathrm{N}$ Engl $\mathrm{J}$ Med 356:213-215

3. Yach D, Stuckler D, Brownell KD (2006) Epidemiologic and economic consequences of the global epidemics of obesity and diabetes. Nat Med 12:62-66

4. Kahn SE, Hull RL, Utzschneider KM (2006) Mechanisms linking obesity to insulin resistance and type 2 diabetes. Nature 444:840-846

5. Ferrannini E, Mari A (2004) Beta cell function and its relation to insulin action in humans: a critical appraisal. Diabetologia 47: 943-956

6. Prentki M, Nolan CJ (2006) Islet beta cell failure in type 2 diabetes. J Clin Invest 116:1802-1812

7. Weir GC, Bonner-Weir S (2004) Five stages of evolving beta-cell dysfunction during progression to diabetes. Diabetes 53(Suppl 3): S16-S21

8. Donath MY, Halban PA (2004) Decreased beta-cell mass in diabetes: significance, mechanisms and therapeutic implications. Diabetologia 47:581-589

9. Rhodes CJ (2005) Type 2 diabetes - a matter of beta-cell life and death? Science 307:380-384

10. Cnop M, Welsh N, Jonas JC, Jorns A, Lenzen S, Eizirik DL (2005) Mechanisms of pancreatic beta-cell death in type 1 and type 2 diabetes: many differences, few similarities. Diabetes 54 (Suppl 2):S97-S107

11. Cnop M, Ladriere L, Hekerman P et al (2007) Selective inhibition of eukaryotic translation initiation factor $2 \alpha$ dephosphorylation potentiates fatty acid-induced endoplasmic reticulum stress and causes pancreatic $\beta$-cell dysfunction and apoptosis. J Biol Chem 282:3989-3997

12. Oyadomari S, Araki E, Mori M (2002) Endoplasmic reticulum stressmediated apoptosis in pancreatic $\beta$-cells. Apoptosis 7:335-345

13. Karaskov E, Scott C, Zhang L, Teodoro T, Ravazzola M, Volchuk A (2006) Chronic palmitate but not oleate exposure induces endoplasmic reticulum stress, which may contribute to INS-1 pancreatic $\beta$ cell apoptosis. Endocrinology 147:3398-3407

14. Schroder M, Kaufman RJ (2005) ER stress and the unfolded protein response. Mutat Res 569:29-63

15. Shi Y, Taylor SI, Seng-Lai T, Sonenberg N (2003) When translation meets metabolism: multiple links to diabetes. Endocr Rev 24:91-101

16. Marciniak SJ, Ron D (2006) Endoplasmic reticulum stress signalling in disease. Physiol Rev 86:1133-1149

17. Wang J, Takeuchi T, Tanaka S et al (1999) A mutation in the insulin 2 gene induces diabetes with severe pancreatic beta-cell dysfunction in the Mody mouse. J Clin Invest 103:27-37

18. Oyadomari S, Takeda K, Takiguchi M et al (2001) Nitric oxideinduced apoptosis in pancreatic beta cells is mediated by the endoplasmic reticulum stress pathway. Proc Natl Acad Sci USA 98:10845-10850

19. Cardozo AK, Ortis F, Storling J et al (2005) Cytokines downregulate the sarcoendoplasmic reticulum pump Ca2+ ATPase $2 b$ and deplete endoplasmic reticulum, leading to induction of endoplasmic reticulum stress in pancreatic beta-cells. Diabetes 54:452-461

20. Kharroubi I, Ladriere L, Cardozo AK, Dogusan Z, Cnop M, Eizirik DL (2004) Free fatty acid and cytokines induce pancreatic $\beta$-cell apoptosis by different mechanisms: role of nuclear factor- $\mathrm{kB}$ and endoplasmic reticulum stress. Endocrinology 145:5087-5096

21. Araki E, Oyadomari S, Mori M (2003) Impact of endoplasmic reticulum stress pathway on pancreatic $\beta$-cells and diabetes mellitus. Exp Biol Med 228:1213-1217 
22. Iyer S, Korada M, Rainbow L et al (2004) Wolcott-Rallison syndrome: a clinical and genetic study of three children, novel mutation in EIF2AK3 and a review of the literature. Acta Paediatr 93:1195-1201

23. Harding HP, Zeng H, Zhang Y et al (2001) Diabetes mellitus and exocrine pancreatic dysfunction in perk-/- mice reveals a role for translational control in secretory cell survival. Mol Cell 7:1153-1163

24. Scheuner D, Vander Mierde D, Song B et al (2005) Control of mRNA translation preserves endoplasmic reticulum function in beta-cells and maintains glucose homeostasis. Nat Med 11:757-764

25. Laybutt DR, Preston AM, Akerfeldt MC et al (2007) Endoplasmic reticulum stress contributes to beta cell apoptosis in type 2 diabetes. Diabetologia 50:752-763

26. Huang C, Lin C, Haatajal L et al (2007) High expression rates of human islet amyloid polypeptide induce endoplasmic reticulum stress-mediated beta cell apoptosis, a characteristic of humans with type 2 but not type 1 diabetes. Diabetes 56:2016-2027

27. Del Guerra S, Lupi R, Marselli L et al (2005) Functional and molecular defects of pancreatic islets in human type 2 diabetes. Diabetes 54(3):727-735

28. Marchetti P, Del Guerra S, Marselli L et al (2004) Pancreatic islets from type 2 diabetic patients have functional defects and increased apoptosis that are ameliorated by metformin. J Clin Endocrinol Metab 89:5535-5541

29. Lupi R, Dotta F, Marselli L et al (2002) Prolonged exposure to free fatty acids has cytostatic and pro-apoptotic effects on human pancreatic islets: evidence that beta-cell death is caspase mediated, partially dependent on ceramide pathway, and Bcl-2 regulated. Diabetes 51:1437-1442

30. Fukui K, Yang Q, Cao Y et al (2005) The HNF-1 target collectrin controls insulin exocytosis by SNARE complex formation. Cell Metab 2:373-384

31. Marselli L, Sgroi DC, Ahn Y-B, Sharma A, Bonner-Weir G, Weir G (2005) Laser capture microdissection provides marked enrichment of beta-cell tissue from human pancreas. Diabetes 54 (Suppl 1):A403

32. Ahn YB, Xu G, Marselli L et al (2007) Changes in gene expression in beta cells after islet isolation and transplantation using laser-capture microdissection. Diabetologia 50:334-342

33. Pirot P, Naamane N, Libert F et al (2007) Global profiling of genes modified by endoplasmic reticulum stress in pancreatic beta cells reveals the early degradation of insulin mRNAs. Diabetologia 50:1006-1014

34. Back Sh, Schroder M, Lee K, Zhang K, Kaufman RJ (2005) ER stress signalling by regulated splicing: IRE1/HAC1/XBP1. Methods 35:395-416

35. Deng S, Vatamaniuk M, Huang X et al (2004) Structural and functional abnormalities in the islets isolated from type 2 diabetic subjects. Diabetes 53:624-632
36. Lin JM, Fabregat ME, Gomis R, Bergsten P (2002) Pulsatile insulin release from islets isolated from three subjects with type 2 diabetes. Diabetes 51:988-993

37. Fernandez-Alvarez J, Conget I, Rasschaert J, Sener A, Gomis R, Malaisse WJ (1994) Enzymatic, metabolic and secretory patterns in human islets of type 2 (non-insulin-dependent) diabetic patients. Diabetologia 37:177-181

38. Ostenson CG, Gaisano H, Sheu L, Tibell A, Bartfai T (2006) Impaired gene and protein expression of exocytotic soluble Nethylmaleimide attachment protein receptor complex proteins in pancreatic islets of type 2 diabetic patients. Diabetes 55:435-440

39. Chehter EZ, Duarte MI, Takakura CF, Longo MA, Laudanna AA (2003) Ultrastructural study of the pancreas in AIDS. Pancreas 26:153-159

40. Junger E, Herberg L, Jeruschke K, Leiter EH (2002) The diabetesprone NZO/Hl strain. II. Pancreatic immunopathology. Lab Invest 82:843-853

41. Zuber C, Fan JY, Guhl B, Roth J (2004) Misfolded proinsulin accumulates in expanded pre-Golgi intermediates and endoplasmic reticulum subdomains in pancreatic beta cells of Akita mice. FASEB J 18:917-919

42. Karaveg K, Siriwardena A, Tempel W et al (2005) Mechanism of class 1 (glycosylhydrolase family 47) $\alpha$-mannosidases involved in $\mathrm{N}$-glycan processing and endoplasmic reticulum quality control. J Biol Chem 280:16197-16207

43. Totani K, Ihara Y, Matsuo I, Koshino H, Ito Y (2005) Synthetic substrates for an endoplasmic reticulum protein-folding sensor, UDP-glucose: glycoprotein glucosyltransferase. Angew Chem Int Ed Engl 44:7950-7954

44. Dejgaard S, Nicolay J, Taheri M, Thomas DY, Bergeron JJ (2004) The ER glycoprotein quality control system. Curr Issues Mol Biol 6:29-42

45. Oyadomari S, Mori M (2004) Roles of CHOP/GADD153 in endoplasmic reticulum stress. Cell Death Differ 11:381-389

46. Loffler M, Bilban M, Reimers M, Waldhausl W, Stulnig TM (2006) Blood glucose-lowering nuclear receptor agonists only partially normalize hepatic gene expression in $\mathrm{db} / \mathrm{db}$ mice. $\mathrm{J}$ Pharmacol Exp Ther 316:797-804

47. Kuchenmeister U, Kuhn G, Wegner J, Nurnberg G, Ender K (1999) Post mortem changes in $\mathrm{Ca} 2+$ transporting proteins of sarcoplasmic reticulum in dependence on malignant hyperthermia status in pigs. Mol Cell Biochem 195:37-46

48. Wang H, Kouri G, Wollheim CB (2005) ER stress and SREBP-1 activation are implicated in beta-cell glucolipotoxicity. J Cell Sci 118:3905-3915

49. Robertson RP (2004) Chronic oxidative stress as a central mechanism for glucose toxicity in pancreatic islet beta cells in diabetes. J Biol Chem 279:42351-42354

50. Lortz S, Tiedge M, Nachtwey T, Karlsen AE, Nerup J, Lenzen S (2000) Protection of insulin-producing RINm5F cells against cytokine-mediated toxicity through overexpression of antioxidant enzymes. Diabetes 49:1123-1130 